\title{
FAKTOR RESIKO KEJADIAN PERDARAHAN PASCA PERSALINAN DI DESA SEI RAYA KABUPATEN KUBU RAYA PROVINSI KALIMANTAN BARAT PONTIANAK (DATA TAHUN 2017 - 2018)
}

\section{Windiyati $^{1}$}

\author{
Akademi Kebidanan Panca Bhakti \\ Email korespondensi: akbidpbpontianak@gmail.com
}

\begin{abstract}
Abstrak
Kematian Ibu pada saat ini masih merupakan salah satu masalah kesehatan reproduksi yang sangat penting. Angka kematian Ibu yang tinggi sesungguhnya dapat dicegah dengan mengetahui resiko ibu hamil yang mempengaruhinya yang dapat menyebabkan perdarahan dalam persalinan bahkan berakibat fatal kematian ibu diantaranya adalah; penanganan komplikasi obstetri dan pertolongan persalinan yang tidak tepat, anemia dalam kehamilan dengan jumlah anak yang banyak serta umur yang terlalu muda dan terlalu tua untuk melahirkan merupakan faktor resiko yang dapat dicegah. Tujuan penelitian ini adalah untuk mengetahui faktor apa yang berhubungan dengan kejadian perdarahan pasca persalinan di Desa Sei raya Kabupaten Kubu Raya, Provinsi Kalimantan Barat (data Tahun 2017 sampai tahun 2018). Penelitian ini merupakan penelitian analitik dengan desain Case Control Study. Pengumpulan data dilakukan antara bulan Desember 2017 - Februari 2018. Jumlah sampel kontrol dan kasus masing-masing adalah 53 dan 159 ibu yang melahirkan. Hasil penelitian menunjukkan pada analisis bivariat yang memiliki hubungan yang bermakna dengan kejadian perdarahan pasca persalinan adalah usia ( $p$ value 0,001 ), Pendidikan ( $p$ value 0,002 ), tenaga penolong ( $\mathrm{p}$ value 0,039 ) dan budaya ( $\mathrm{p}$ value 0,000 ). Sedangkan pada analisis multivariat faktor yang paling dominan adalah faktor budaya dengan mempertimbangkan faktor tenaga penolong dan faktor umur ( $\mathrm{p}$ value 0,000 dan OR 7,057). Perlu diadakan penyuluhan dan pemberian informasi yang jelas baik secara formal ataupun informal tentang budaya yang berdampak buruk pada ibu bersalin.
\end{abstract}

Kata Kunci : kematian ibu, perdarahan, faktor risiko

\section{Pendahuluan}

Kematian Ibu pada saat ini masih merupakan salah satu masalah kesehatan reproduksi yang sangat penting. Angka Kematian Ibu (AKI) di Indonesia masih sangat tinggi bila dibandingkan dengan negara - negara ASEAN lainnya, Angka kematian Ibu yang tinggi sesungguhnya dapat dicegah dengan mengetahui resiko ibu hamil yang mempengaruhinya yang dapat menyebabkan perdarahan dalam persalinan bahkan berakibat fatal kematian ibu diantaranya adalah, penanganan komplikasi obstetric dan pertolongan persalinan yang tidak tepat, anemia dalam kehamilan dengan jumlah anak yang banyak serta umur yang terlalu muda dan terlalu tua untuk melahirkan merupakan faktor resiko yang dapat dicegah (Saifuddin, 2010).

$$
\text { Data WHO (World Heath }
$$

Organitation) dalam lutfia memperlihatkan data Sebanyak 536.000 perempuan meninggal akibat persalinan. diantaranya 99\% kematian ibu akibat masalah persalinan atau kelahiran terjadi di negara-negara berkembang. Rasio kematian ibu di negaranegara berkembang merupakan tertinggi jika dibandingkan dengan rasio kematian ibu di 9 negara maju dan 51 negara persemakmuran. Dan Angka Kematian Ibu (AKI) ditahun 2011 terdapat $81 \%$ diakibatkan karena komplikasi

\footnotetext{
${ }^{1}$ Dosen Akademi Kebidanan Panca Bhakti Pontianak
} 
selama kehamilan, persalinan dan nifas. Bahkan sebagian besar dari kematian ibu disebabkan karena perdarahan, infeksi dan preeklamsia data juga menunjukkan bahwa $25 \%$ dari kematian maternal disebabkan oleh perdarahan pasca persalinan dan diperkirakan 100.000 kematian maternal tiap tahunnya. Dan Berdasarkan Data Statistik Nasional Amerika Serikat menyebutkan sekitar 8\% dari kematian ibu disebabkan oleh perdarahan pasca persalinan. Di Negara industri, perdarahan pasca persalinan biasanya terdapat pada 3 peringkat teratas penyebab kematian maternal, bersaing dengan embolisme dan hipertensi. Di beberapa Negara berkembang angka kematian maternal melebihi 1000 wanita tiap 100.000 kelahiran hidup (WHO, 2010).

Angka kematian ibu di Kalimantan Barat (Kalbar) tercatat 392/100.000 KH (Profil Kalbar 2010), angka ini masih diatas angka Nasional yakni 305/100.000 KH (Kemenkes 2015). Penyebab kematian ibu yang paling utama adalah perdarahan pasca persalinan $(67 \%)$, infeksi $(8 \%)$, toxemia (7 $\%)$ dan Abortus (10\%), data diatas didukung oleh data profil KalBar yakni hampir 90\% ibu perdarahan pasca persalinan terjadi dirumah karena pertolongan persalinan oleh dukun tradisional dan $80 \%$ kasus perdarahan yang dirujuk ke rumah sakit akibat perdarahan pasca persalinan.

Berdasarkan laporan Profil Kesehatan Kalimantan Barat data kesehatan Ibu dan Anak (KIA) tahun 2015 Kabupaten Pontianak ada 39 kasus perdarahan pasca persalinan yang dirujuk ke RSUD Dokter Sudarso dan 4 diantaranya meninggal. Dan dari Puskesmas Sei raya dalam tidak ada data sedangkan dari Polindes Sei Raya Dalam terdapat 12 kasus perdarahan pasca persalinan.

Berdasarkan data profil Dinas Kesehatan Provinsi Kalimantan Barat tahun 2015, tercatat sebanyak 96 kasus kematian ibu, dengan rincian sebanyak 4 kasus kematian ibu hamil, 90 kasus kematian ibu pada saat persalinan serta sebanyak 3 kasus kematian ibu nifas. Sehingga jika dihitung, Angka Kematian Ibu (AKI) dengan jumlah kelahiran hidup sebanyak 90.117, maka Angka Kematian Ibu (AKI) di Provinsi KalBar pada tahun 2017 adalah sebesar 107 per 100.000 kelahiran hidup (Profil DinKes Kalimantan Barat, 2015).

Perdarahan pasca persalinan merupakan penyebab kematian maternal terbanyak, semua wanita yang sedang hamil memiliki resiko perdarahan pasca persalinan. Perdarahan pasca persalinan yang menyebabkan kematian ibu ini sebanyak $45 \%$ terjadi pada 24 jam pertama setelah bayi lahir, 68-73\% dalam satu minggu setelah bayi lahir dan $82-88 \%$ dalam dua minggu setelah bayi lahir.

Penyebab perdarahan pasca persalinan adalah akibat Atonia uteri (lemahnya otot rahim sehingga tidak dapat berkontraksi dengan baik) . predisposisi ini diantaranya adalah umur, paritas (jumlah anak yang dilahirkan), partus lama, pengunaan anestesi dan penanganan Manajemen aktif kala tiga pada persalinan, sedangkan faktor resiko yang 
dapat mempengaruhi terjadinya perdarahan pasca persalinan menurut WHO, adalah umur, paritas, sosio ekonomi, pendidikan, pekerjaan, sosial budaya (kesadaran masyarakat), tenaga pertolongan persalinan serta ibu yang tidak pernah Antenatal Care. Adapun Faktor Predisposisi yang dapat menyebabkan perdarahan pasca persalinan adalah peningkatan tekanan darah (lebih dari 140/90 $\mathrm{mmHg}$ ), polihidramnion atau kehamilan multiple, sectio caesarea sebelumnya, persalinan lama, penggunaan syntocinon secara tidak bijaksana, persalinan presipitatus, kelahiran supinasi atau semirekumben, pelahiran instrumental, kelahiran caesar, kesalahan penatalaksanaan kala III persalinan, anastesia umum, gangguan pembekuan. Sedangkan penyebab terjadinya perdarahan pasca persalinan antara lain atonia uteri, luka jalan lahir, retensio plasenta dan gangguan pembekuan darah (Marmi, 2012).

Dari data yang di peroleh di Kantor Desa Sei raya diketahuin bahwa jumlah penduduk 3876 jiwa mayoritas masyarakat hidup sebagai petani dengan ekonomi kebawah dan adat istiadat yang turun temurun serta sebagian besar mendapat dana bantuan Jaringan Pengamanan Sosial (JPS), pertolongan persalinan di Parit Semben, Parit H. Muchsin, Parit Baru dan Parit Tengkorak desa Sei raya lebih banyak ditolong oleh dukun tradisional atau dukun keluarga, karena masih merupakan hubungan keluarga misalnya, nenek, bibi atau ibunya sendiri yang menolong persalinan, pemeriksaan kehamilan jarang dilakukan serta kebiasaan pantang makanan tertentu bagi ibu hamil dan masyarakat meyakini dan percaya jika ada yang meninggal dalam persalinan dianggap wajar atau disebut ketegoran ( bahasa lokal melayu / yang berarti ada melanggar adat melayu ) dan apabila perdarahan dalam persalinan dianggap baik karena mengeluarkan darah kotor bahkan jika darah tidak banyak keluar maka ibu bersalin akan diberi jamu- jamuan tradisional untuk mengeluarkan darah yang banyak.

Upaya untuk mempercepat penurunan Angka kematian ibu karena perdarahan pasca persalinan sudah dilakukan oleh Dinas Kesehatan Kubu Raya. Departemen Kesehatan juga melakukan terobosan dengan menempatkan bidan desa berdasarkan Keputusan Presiden (KepPres) tahun 1994 serta pembinaan dukun oleh puskesmas binaan. Jumlah bidan yang bertugas di Desa Sei Raya sebanyak 8 orang yang tersebar di kelurahan dan desa dan 6 orang bidan di Puskesmas. Sampai saat ini angka perdarahan pasca persalinan masih tinggi dibandingkan dengan desa yang lain serta pemanfaatan pelayanan kesehatan yang masih kurang. Oleh karena itu dengan melakukan penelitian pada ibu - ibu yang mengalami perdarahan pasca persalinan, diharapkan dapat diketahui faktor risiko apa yang berhubungan dengan kejadian perdarahan pasca persalinan di Desa Sei Raya Kabupaten Kubu Raya, Propinsi Kalimantan Barat. 
Metode

Penelitian ini merupakan penelitian analitik dengan desain Case Control Study. Pengumpulan data dilakukan antara bulan Desember 2017 - Februari 2018. Jumlah sampel kontrol dan kasus masing-masing adalah 53 dan 159 ibu yang melahirkan. Analisa bivariat menggunakan odds ratio dan uji statistic chi square sedangkan pada analisa multivariat menggunakan model regresi.

Hasil dan Pembahasan

Tabel 1. Hubungan Antar Variabel Independen dan Variabel Dependen

\begin{tabular}{|c|c|c|c|c|c|c|}
\hline \multirow{2}{*}{ Variabel } & \multicolumn{2}{|c|}{ Kasus } & \multicolumn{2}{|c|}{ Kontrol } & \multirow{2}{*}{ P Value } & \multirow{2}{*}{ OR $(95 \% \mathrm{CI})$} \\
\hline & $\mathrm{N}$ & $\%$ & $\mathrm{~N}$ & $\%$ & & \\
\hline \multicolumn{7}{|l|}{ Umur } \\
\hline$<20$ dan $>35$ tahun & 14 & 26,4 & 13 & 18,2 & \multirow{2}{*}{0,001} & 4,032 \\
\hline 20 tahun -35 tahun & 39 & 73,6 & 146 & 91,8 & & $(1,752-9,278)$ \\
\hline \multicolumn{7}{|l|}{ Fisik } \\
\hline Berat & 23 & 43,3 & 62 & 39 & \multirow{3}{*}{0,174} & \multirow{3}{*}{$\begin{array}{c}2,353 \\
(0,936-5,916)\end{array}$} \\
\hline Sedang & 20 & 37,7 & 80 & 50,3 & & \\
\hline Ringan & 10 & 19 & 17 & 10,7 & & \\
\hline \multicolumn{7}{|l|}{ Pendidikan } \\
\hline SD & 22 & 41,5 & 104 & 65,4 & \multirow{4}{*}{0,002} & \multirow{4}{*}{$\begin{array}{c}7,879 \\
(1,752-35,432)\end{array}$} \\
\hline SMP & 16 & 30 & 41 & 25,8 & & \\
\hline SMA & 10 & 19 & 11 & 6,9 & & \\
\hline PT & 5 & 9,5 & 3 & 1,9 & & \\
\hline \multicolumn{7}{|l|}{ Paritas } \\
\hline 1 dan $>4$ anak & 36 & 67,2 & 90 & 56,6 & \multirow{2}{*}{0,142} & 1,624 \\
\hline $2-4$ anak & 17 & 32,8 & 69 & 43,4 & & $(0,842-2,130)$ \\
\hline \multicolumn{7}{|l|}{ Sosio ekonomi } \\
\hline Rendah & 38 & 71,7 & 127 & 79,9 & \multirow{2}{*}{0,223} & 0,638 \\
\hline Tinggi & 15 & 28,3 & 32 & 20,1 & & $(0,313-1,301)$ \\
\hline \multicolumn{7}{|l|}{ Penolong } \\
\hline Non nakes & 31 & 58,5 & 67 & 42,1 & \multirow{2}{*}{0,039} & 1,935 \\
\hline Nakes & 22 & 41,5 & 92 & 57,9 & & $(1,030-3,635)$ \\
\hline \multicolumn{7}{|l|}{ ANC } \\
\hline$<4$ kali & 32 & 60,3 & 114 & 71,6 & \multirow{2}{*}{0,128} & 0,602 \\
\hline$>4$ kali & 21 & 39,7 & 45 & 28,4 & & $(0,314-1,152)$ \\
\hline \multicolumn{7}{|l|}{ Budaya } \\
\hline $\mathrm{Ya}$ & 39 & 73,6 & 45 & 28,3 & \multirow{2}{*}{0,000} & 7,057 \\
\hline Tidak & 14 & 26,4 & 114 & 71,7 & & $(3,500-14,231)$ \\
\hline
\end{tabular}

Berdasarkan variabel umur diatas pada kelompok kasus, diketahui bahwa 26,4\% ibu melahirkan dalam kelompok ibu dengan umur kurang dari 20 tahun dan diatas 35 tahun mengalami perdarahan dibandingkan kelompok kontrol sebanyak $8,2 \%$. Nilai $p$ value yang diperoleh adalah 0,001 artinya yaitu bahwa ada perbedaan persentase perdarahan pasca persalinan antara ibu yang berumur $<20$ dan $>35$ tahun dengan ibu yang berumur 20-35 tahun. Sehingga dapat disimpulkan bahwa umur memiliki hubungan dengan kejadian perdarahan pasca persalinan. Apabila dilihat pada nilai OR dengan tingkat kepercayaan 95\% sebesar 4,032 maka dapat diartikan bahwa ibu yang berumur $<20$ dan 
>35 tahun berisiko 4,03 kali mengalami perdarahan dibandingkan usia 20-35 tahun.

Pada variabel kedua diatas, dapat disimpulkan bahwa pada kelompok kasus, ibu yang memiliki aktivitas fisik berat lebih banyak dibanyak kelompok kontrol yaitu sebesar $43,3 \%$. Nilai $p$ value yang diperoleh adalah 0,174 yang berarti aktivitas fisik pada ibu tidak berhubungan secara bermakna dengan perdarahan pasca persalinan.

Hasil analisa variabel Pendidikan pada tabel diatas menunjukkan bahwa Pendidikan dengan level SD pada kelompok kasus memiliki persentase lebih kecil dibandingkan pada kelompok kontrol yaitu $41,5 \%$. Nilai $\mathrm{P}=$ 0,002 artinya terdapat hubungan yang bermakna antara tingkat Pendidikan dengan kejadian perdarahan pasca persalinan. Nilai OR dengn CI 95\% diketahui sebesar 7,879, artinya semakin kecil Pendidikan ibu maka ibu akan berisiko mengalami perdarahan sebesar 7,87 kali.

Analisa variabel paritas diatas menunjukkan bahwa paritas dengan jumlah 1 dan >4 pada kelompok kasus lebih besar persentase kejadian perdarahan dibandingkan pada kelompok kontrol yaitu $67,2 \%$. Nilai $\mathrm{P}=0,142$ yang berarti tidak ada hubungan yang bermakna antara paritas dengan kejadian perdarahan.

Berdasarkan analisa pada variabel sosio ekonomi tabel 1 diatas, dapat diketahui bahwa pada kelompok kasus, ibu dengan ekonomi rendah persentase mengalami kejadian perdarahan lebih rendah yaitu sebesar 71,7\%. Nilai $\mathrm{P}=0,223$ artinya sosio ekonomi tidak berhubungan secara bermakna terhadap kejadian perdarahan pasca bersalin.

Pada variabel tenaga penolong, sebesar $58,5 \%$ ibu yang ditolong oleh non kesehatan pada kelompok kasus mengalami kejadian perdarahan pasca bersalin. Nilai $P$ value yang diperoleh yaitu 0,039 yang berarti ada hubungan yang bermakna antara tenaga penolong persalinan dengan kejadian perdarahan. Nilai OR yang diperoleh yaitu 1,935 artinya ibu yang ditolong oleh non kesehatan akan berisiko sebesar 1,93 kali mengalami kejadian perdarahan disbanding ibu yang ditolong oleh tenaga kesehatan.

Variabel ANC yang tertera pada tabel diatas dapat diambil kesimpulan yaitu persentase ibu yang ANC nya $<4$ kali pada kasus lebih banyak dibandingkan ibu dengan ANC >4 kali yaitu sebesar 60,3\%. Hasil analisis uji statistic menunjukkan nilai $\mathrm{p}$ value yang diperoleh yaitu 0,128 artinya ANC tidak berhubungan secara signifikan dengan kejadian perdarahan pasca persalinan.

Sebesar $73,6 \%$ ibu yang mengikuti budaya pada kelompok kasus diatas mengalami perdarahan dibandingkan kelompok kontrol. Nilai $\mathrm{p}$ value pada uji statistic menunjukan bahwa ada hubungan yang signifikan antara budaya dengan kejadian perdarahan pasca persalinan yiatu 0,000 . Adapun nilai OR yang diperoleh adalah 7,057 , ini berarti ibu yang mengikuti budaya berisiko 7,05 kali mengalami kejadian perdarahan dibandingkan yang tidak mengikuti budaya. 
Syarat melakukan analisa multivariat adalah variabel yang diuji pada uji statistic bivariat memiliki nilai signifikasi <0,05. Berdasarkan hasil diatas, diketahui bahwa yang memenuhi syarat ada 4 variabel yaitu variabel umur, pendidikam, penolong dan budaya. Keempat variabel ini dimasukan kedalam uji multivariat untuk dilakukan pemilihan model. Model terbaik dengan pertimbang signifikansi $<0,5$ akan diambil sementara yang tidak akan dikeluarkan secara berurutan. Peneliti melakukan 2 kali pemodelan pada analisa multivariat, sehingga diperoleh hasil sebagai berikut:

Tabel 2. Analisa Multivariat

\begin{tabular}{ccc}
\hline Variabel & Model I & Model II \\
& OR 95\% CI & OR 95\% CI \\
\hline \multirow{2}{*}{ Umur } & $* 3,293$ & $* 2,640$ \\
& $(1,204-9,005)$ & $(1,071-6,508)$ \\
Penolong & $* 3,429$ & $* 2,047$ \\
& $(1,440-8,162)$ & $(1,012-4,140)$ \\
Budaya & $* 6,985$ & $* 6,618$ \\
& $(3,145-15,516)$ & $(3,206-13,662)$ \\
Pendidikan & 1,790 & - \\
\hline
\end{tabular}

$*$ nilai $\mathrm{p}$ value $<0,05$

Berdasarkan hasil diatas, pemodelan multivariat diatas, ternyata variabel yang berhubungan bermakna dengan kejadian perdarahan pasca persalinan adalah mur, penolong persalinan dan budaya. Hasil analisis yang diperoleh berdasarkan nilai OR yang paling dominan adalah OR pada variabel budaya dengan nilai 6,618 (95\% CI: 3,20613,662) yang berarti ibu yang mengikuti budaya yang merugikan kesehatan berisiko mengalami perdarahan pasca persalinan 6,618 kali dibandingkan ibu yang tidak mengikuti budaya yang buruk. Hal ini diperoleh setelah variabel dikontrol oleh variabel umur dan pertolongan persalinan.

Faktor-Faktor yang Berhubungan dengan Kejadian Perdarahan Pasca Persalinan

Ada banyak faktor penyebab kejadian perdarahan pasca persalinan (perdarahan postpartum) diantaranya adalah umur, aktivitas fisik, Pendidikan, paritas, penolong persalinan dan lain-lain. Prawiroharjo (2010) pada bukunya mengatakan bahwa umur yang berisiko pada waktu hamil akan mengalami komplikasi persalinan. Pada analisa bivariat tabel 1 sebelumnya diketahui bahwa variabel umur memiliki hubungan dengan kejadian perdarahan pasca persalinan dengan nilai $\mathrm{p}$ value $<0,05$.

Hasil ini sejalan dengan teori yang disampaikan oleh Prawirohardjo (2009) yang mengatakan bahwa umur yang terlalu muda dan terlalu tua, umur dibawah 20 tahun ternyata $2-5$ kali lebih tinggi dari pada umur 20 - 29 tahun, kemudian meningkat sesudah umur 30 - 35 tahun.Umur ibu dapat dijadikan salah satu alat ukur dalam menetapkan diagnosa apakah kehamilan atau persalinan beresiko atau tidak beresiko. 
Semakin rendah umur seseorang dalam kehamilan, maka semakin beresiko terhadap kehamilan dan persalinannya. Begitu juga sebaliknya semakin tinggi umur seorang dalam kehamilan dapat mempengaruhi keadaan optimalisasi ibu maupun janin pada persalinan yang akan dihadapi.

Selain umur, aktivitas fisik juga berhubungan dengan kejadian perdarahan. Hasil penelitian menunjukkan bahwa nilai $\mathrm{p}$ value yang diperoleh >0,05. Hal ini menunjukkan bahwa aktivitas fisik tidak berhubungan secara signifikan dengan kejadian perdarahan pasca persalinan. Temuan ini tidak sejalan dengan yang disampaikan oleh Rabe (2000) yang mengatakan bahwa pekerjaan fisik berat yang dilakukan ibu selama kehamilannya pada Trimester III dan selama masa nifas yang memerlukan kekuatan fisik akan mempengaruhi terjadinya perdarahan postpartum.

Pada variabel ketiga yang diteliti yaitu variabel Pendidikan, diperoleh hasil dimana $\mathrm{p}$ value $<0,05$ yang berarti Pendidikan memiliki hubungan yang signifikan dengan kejadian perdarahan pasca persalinan atau postpartum. Temuan ini sejalan dengan yang disampaikan oleh Departemen Kesehatan (1999) yang mengatakan bahwa Tingkat pendidikan yang tinggi akan membuat suatu kehamilan lebih aman. Ibu dengan pendidikan yang tinggi lebih baik pengetahuannya tentang kesehatan dan dapat mencari pelayanan persalinan pada tenaga kesehatan.
Temuan penelitian berikutnya pada variabel paritas, diketahui bahwa nilai $\mathrm{p}$ value yang diperoleh >0,05 yang menunjukkan bahwa paritas tidak memiliki hubungan yang signifikan dengan kejadian perdarahan. Temuan ini tidak sejalan dengan yang disampaikan oleh Harry Oxorn dan William R.forte (2010) yang menyatakan bahwa Semakin banyak melahirkan anak maka uterus akan semakin elastis dan ukuran akan bertambah besar ukurannya sehingga kontraksi uterus akan semakin lemah dan terjadilah perdarahan. Selain itu didalam penelitian Satriyandari dan Nena (2017) menyebutkan bahwa terdapat 3 faktor yang berhubungan dengan kejadian perdarahan, diantaranya yaitu paritas, drip oksitosin dan anemia dengan $p$ value $<0,05$.

Pada variabel sosio ekonomi, diketahui bahwa tidak ada hubungan yang signifikan antara sosio ekonomi dengan kejadian perdarahan pasca persalinan dengan nilai $\mathrm{p}$ value $>0,05$. Hasil ini sejalan dengan yang disampaikan oleh Prawiroharjo (2010) dan Rabe (2000) yang menyebutkan bahwa sosio ekonomi bukanlah penyebab langsung dari perdarahan dan tidak aan berpengaruh terhadap kesehatan.

Hasil analisis yang dilakukan pada variabel penolong menunjukkan bahwa penolong persalinan berhubungan secara bermakna dengan kejadian perdarahan postpartum dengan nilai $\mathrm{p}$ value $<0,05$. Temuan ini sesuai dengan yang disampaikan oleh Rustam (2012) yang mengatakan bahwa persalinan yang ditolong oleh tenaga 
kesehatan dengan menerapkan manajemen aktif kala III makan dapat mencegah terjadinya retensio plasenta secara langsung dapat mencegah perdarahan, disamping itu tenaga kesehatan juga memiliki keahlian dalam bidangnya yang dapat memberikan keamanan atau kebersihan dalam persalinan. Selain itu persalinan dengan dukun tradisional dan bukan tenaga kesehatan lebih besar risiko terjadi perdarahan postpartum karena dukun akan lebih banyak melakukan intervensi yang akan mengakibatkan perdarahan (DepKes, 2001)

Temuan pada analisis variabel ANC menunjukkan bahwa tidak ditemukan hubungan yang signifikan antara ANC dengan perdarahan postpartum yang dapat dilihat pada nilai $p$ value $>0,05$. Hasil ini tidak sesuai dengan yang disampaikan oleh Departemen Kesehatan (2001) yaitu ibu yang pernah melakukan pemeriksaan kehamilannya minimal 4 kali selama kehamilannya akan lebih kecil resiko mengalami perdarahan postpartum dibanding yang tidak pernah sama sekali.

Penelitian pada kelompok kasus ibu yang mempraktikan budaya yang merugikan kesehatan seperti pengurutan pada perut waktu hamil dan pengurutan saat selesai persalinan dapat menyebabkan perdarahan. Berdasarkan temuan pada analisis bivariat, diketahui bahwa budaya berhubungan secara signifikan dengan kejadian perdarahan postpartum dengan nilai signifikasi $<0,05$.

Temuan tersebut sejalan dengan yang disampaikan oleh Rabe (2000) dan Molnar et al (2014) yaitu budaya yang merugikan kesehatan merupakan suatu konsep penyebab faktor yang dapat berisiko terhadap kesehatan dan merugikan kesehatan reproduksi wanita seperti infeksi, perdarahan serta kematian ibu.

Bila dilihat pada hasil model multivariat diketahui bahwa ada tiga variabel yang berpengaruh terhadap risiko terjadinya perdarahan pasca persalinan yaitu umur, tenaga penolong persalinan dan budaya. Dari ketiga variabel tersebut yang memiliki risiko paling dominan adalah budaya. Bila dilihat dari faktor umur, seperti yang disampaikan oleh Varney (2009), pada usia <20, otot-otot yang berhubungan dengan persalinan belum matang dan belum siap terbentuk sehingga resiko mengalami komplikasi saat persalinan sering terjadi misalnya perdarahan pasca persalinan.

Pada usia >35 tahun, organ-organ vital yang berhubungan dengan persalinan seperti otot-otot panggul, uterus serta tulang panggul sudah kaku yang dapat juga menyebabkan perdarahan postpartum atau perdarahan pasca persalinan. Selain usia, tenaga penolong persalinan juga memegang peranan penting.

Menurut Prawiroharjo (2010), ibu yang melahirkan dengan tenaga non kesehatan seperti dukun akan sangat berisiko terhadap kejadian perdarahan, oleh sebab itu persalinan seharusnya ditolong oleh tenaga kesehatan, karena pada saat sesudah bayi lahir dan plasenta belum lahir sangat diperlukan tenaga terampil yang dapat mengelola kelahiran plasenta sedini mungkin dengan menerapkan manajemen aktfi kala III untuk mencegah 
terjadinya retensio plasenta yang mengakibatkan terjadinya perdarahan.

Budaya yang buruk dan diikuti oleh ibu hamil juga sangat beriko terhadap kejadian perdarahan. Budaya yang mempraktikan halhal merugikan kesehatan seperti pemijatan pada perut waktu hamil dan pemijatan fundus sesudah bayi lahir serta minum jamu-jamuan sangat bertentang dengan yang dikemukakan oleh Stoppard (2010). Mariam menyebutkan bahwa untuk mencegah perdarahan postpartum cukup dirangsang dengan massage uterus, supaya uterus dapat berkontraksi dengan baik.

\section{Kesimpulan}

Kesimpulan yang dapat diambil dalam penelitian ini itu pada analisa bivariat ditemukan 4 faktor yang berhubungan denga kejadian perdarahan pasc persalinan sedangkan pada model terakhir analisis multivariat faktor yang paling dominan adalah faktor budaya dengan mempertimbangkan faktor tenaga penolong dan faktor umur ( $p$ value 0,000 dan OR 7,057). Perlu diadakan penyuluhan dan pemberian informasi yang jelas baik secara formal ataupun informal tentang budaya yang berdampak buruk pada ibu bersalin.

\section{Daftar Pustaka}

Departemen Kesehatan. 1999. Materi ajar modul safe motherhood. Jakarta: FKM UI

2001. Buku Kesehatan Ibu dan Anak. Jakarta: DepKes RI

. 2010. Profil Kesehatan Kalimantan Barat 2010. Pontianak: Dineks Provinsi Kalimantan Barat

Dinas Kesehatan Kalimantan Barat. 2015. Profil Kesehatan Kabupaten Pontianak. Pontianak: Dineks Provinsi Kalimantan Barat

Kemenkes. 2015. Rencana Strategis Kementerian Kesehatan Tahun 20152019. Jakarta: Kementerian Kesehatan RI

Keputusan Presiden. 1994. Tentang Pengangkatan Bidan Sebagai Pegawai Tetap. Jakarta: Presiden Republik Indonesia

Marmi. 2012. Intranatal Care: Asuhan Kebidanan Pada Persalinan. Yogyakarta: Pustaka Belajar

Molnar, Joseph Andrew., Underdown, Mary Jane and William Andrew Clark. Nutrition and chronic wounds. Advances in wound care, Volume 3, Number $11 \quad 2014 \quad$ Doi: 10.1089/Wound.2014.0530

Oxorn, Harry. 2010. Ilmu Kebidanan Patologi Dan Fisiologi Persalinan. Yogyakarta: ANDI

Prawirohardjo, Sarwono. 2009. Ilmu Kebidanan. Jakarta: Yayasan Bina Pustaka

Sarwono Prawirohardjo . 2010. Ilmu Kebidanan. Jakarta: Yayasan Bina Pustaka Sarwono Prawirohardjo

Rabe, Thomas. 2000. Haemoragia Postpartum. Australia

Rustam, Mochtar. 2012. Sinopsis Obstetri: Obstetri Fisiologi, Obstetri Patologi. Jakarta: EGC

Saifuddin, Abdul Bari. 2010. Ilmu Kebidanan, edisi.4. Jakarta: Bina Pustaka Sarwono Prawirohardjo 
Satriyandari, Yekti dan Nena Rizki Hariyati. 2017. Faktor-Faktor Yang

Mempengaruhi

Kejadian Perdarahan Postpartum. Journal of Health Studies, Vol. 1, No.1, Maret 2017: 49-64

Stoppard, Miriam. 2010. Panduan Kesehatan Keluarga. Jakarta: Erlangga

Varney, Helen. 2009. Buku Ajar Asuhan Kebidanan Edisi 4. Jakarta : EGC

WHO. 2010. Maternal Mortality. World Health Organization 